\title{
Exploring the Preconditions for a Developmental Science: Hegelian Metaphysics and Dialectics
}

\author{
Denis Kiyak Ebbesen ${ }^{1}$ [D . Jeppe Olsen ${ }^{1}$
}

Received: 12 March 2020 / Revised: 25 March 2021 / Accepted: 27 March 2021

(c) The Author(s), under exclusive licence to Springer Nature Switzerland AG 2021

\begin{abstract}
In this article, we explore the metaphysics of Hegelian dialectics and its implications for a developmental science. More specifically, we investigate how Hegel initiated the move from classical mechanicism to dialectics, thus rearranging the ruling scientific logic at his time. We do this by introducing some of the metaphysical assertions implied by mechanicism and showing how these assertions are scientifically inadequate in explicating the relation between the empirical matter and abstract representation of a given (developmental) phenomenon. This claim leads us to a discussion of the theory of knowledge offered by Hegel as opposed to Kant, and how these theories relate to the struggle between process and structure. Finally, we find that the subject is displaced in between observation and experience and thus epistemically constrained in its access to empirical matters. This fact draws attention to the importance of considering the metaphysical aspects of the sensemodalities, and how such aspects relate to any given developmental phenomenon. Overall the article illustrates the potentials of Hegelian dialectics for avoiding entrenched dualisms and static oppositions in future research.
\end{abstract}

\section{Hegelian Dialectics: a Viral Gift to Human Knowledge}

[T]ruly to escape Hegel involves an exact appreciation of the price we have to pay to detach ourselves from him. It assumes that we are aware of the extent to which Hegel, insidiously perhaps, is close to us; it implies a knowledge, in that which permits us to think against Hegel, of that which remains Hegelian. We have to determine the extent to which our anti-Hegelianism is possibly one of his tricks directed against us, at the end of which he stands, motionless, waiting for us. (Foucault quoted in Keenan, 2004, xxiv).

Hegelian dialectics has received somewhat of a revival in philosophy of science in the last decade (Brandom, 2019; Pfeifer, 2012; Žižek, 2012). Dating back to Vygotsky, the theme of dialectics is also deeply entwined with various axiomatic foundations of

Denis Kiyak Ebbesen

denis.ebbesen@psy.ku.dk

Jeppe Olsen

fiskersoen@gmail.com

1 University of Copenhagen, Copenhagen, Denmark 
psychological research, which are still being developed in contemporary psychology (see e.g. Engelsted, 2017; Mammen \& Mironenko, 2015; Valsiner, 2000), and thrive in the fields of cultural- and developmental psychology (Hviid \& Villadsen, 2014; Pedersen \& Bang, 2016).

In opposition to this, Hegel-inspired research stands other, and more anti-Hegelian, trends in the human- and social-sciences. For example, Hegel has been scorched in many major works of the post-war period, and the use of dialectics in philosophy, politics, and science has been heavily critiqued from various intellectual domains (Bunge, 2012; Popper, 2012; Sartre, 1978). Furthermore, some of the most cited humanist theorists in Denmark (Foucault, Deleuze, and Latour [Pedersen et al., 2015]) are poststructuralists who are heavily antagonistic towards Hegelian dialectics.

These circumstances qualify an investigation into Hegelian metaphysics and its scientific relevance, since, ultimately, whether or not dialectical research can be trusted to provide us with adequate perceptions about higher-order phenomena, boils down to whether or not there is a logical coherence between research axioms, theory, methodology, methods, and empirical data-construction (Ebbesen \& Olsen, 2018a, b, p. 8). Hegel's dialectics can be viewed as an ambition on behalf of thought, to provide exactly such logical coherence, i.e., a metaphysics, and which therefore has to permeate every step in the concrete scientific process, from making clear one's research axioms to generating hypotheses and collecting data. Thus, in this article, we explore the metaphysics of Hegelian dialectics and distill its implications for a developmental science.

Our purpose is not to advertise nostalgia for Hegel. Rather, our project is to illuminate how Hegel's work can help us explicate certain issues for a progressive developmental science, including an unsurpassable criteria of scientific demarcation, namely, that any project purporting to be scientific must be able to account for a (logical) relation between the empirical matter at hand and the abstract representation of that empirical matter. Thus, Hegel has put forth a task for the modern sciences which must be considered obligatory in so far as the given science strives towards a rational and systematic practice of theory-building. ${ }^{1}$

\section{The Ambition of Hegel's Dialectics}

To cancel established oppositions is the sole interest of Reason. But this interest does not mean that Reason is opposed to opposition and limitation in general; for necessary opposition is one factor of life, which forms itself by eternally opposing itself, and in the highest liveliness totality is possible only through restoration from the deepest fission

(Hegel [1801/2002] p. 34).

Hegel is often rejected by many as an absolute idealist, and his logical systems are often caricatured as madman's organismic hyper-generalization that makes both subject, society, the world, and cosmos one big coherent organism (Beiser, 2005, p. 59). It is important to

\footnotetext{
1 It is worth mentioning that the term Wissenschaft (used by Hegel and his fellow thinkers) has significantly different connotations than the term science (Burke, 2015, p. 6). Wissenschaft does not imply any type of institutional affiliation but refers to reflective modes of investigation through which different forms of knowledge can be organized. That is, it connotes a praxis rather than titles. Furthermore, Wissenschaft refers to a broader conception of empirical matters than merely data collection and analysis.
} 
note that such caricature is often based on a misunderstanding of the project of German idealism. Thus, the early reception of Hegel in the English speaking world was marked by (or biased towards) a historically specific conception of idealism, which connects idealism to immaterialism (thus dichotomizing idealism and materialism). This conception can be found in for example the works of George Berkeley (1685-1753). As Redding (2020, Sect. 2.1) states: "With the possible exception of Leibniz, the idealism of the Germans was not committed to the type of doctrine found in Berkeley according to which immaterial minds, both infinite (God's) and finite (those of humans), were the ultimately real entities, with apparently material things to be understood as reducible to states of such minds - that is, to ideas in the sense meant by the British empiricists."

Hence, the definition of idealism and materialism propagated by British empiricists has some misleading attributes. For example, Plato's take on ideal forms does not necessarily imply a mind or a God; it is rather the ideal forms which give rise to mind and gods. Likewise, the identification of idealism with immaterialism is not at all representative of what the German idealists meant by ideas or idealism. German idealism was much more influenced by the philosophy of Baruch de Spinoza ${ }^{2}$ (1632-1677), who tried to establish a conception of ideas as immanent to the material world.

As such, one can suspend this straw man of immaterialism from Hegelian dialectics, and instead understand the relevance of Hegel's system in relation to the construction of developmental theories.

As Hegel states in the opening quote of this section, one will never achieve insight into development by domesticating and smoothing out a phenomenon in motionless dichotomies (just think of the mind-body dualism). However, neither is it adequate for a developmental theory to claim, as the tradition from Heraclitus, that everything is in a continual flow of change, thus making the entity an epiphenomenon. The Hegelian subject is "simultaneously a projection and a prerequisite of its own object" (Copilas, 2019, p. 176). Hence, the big question implied by Hegelian dialectics is the age-old mystery of how being and becoming traverse. Or in other words, how a phenomenon (defined as an event related to a discretely defined entity) can both become and subsist through development. To shed light on this theme, let us first take a look at classical mechanicism and see how this question has been historically dealt with and explained (away).

\section{Rearranging the Science of Logic}

With notable precursors such as Galilei (1564-1642) and Descartes (1596-1650), mechanicism was the ruling scientific worldview at Hegel's time. ${ }^{3}$ During German romanticism, Hegel found himself stumbling across natural philosophy and the teachings of natural development. Hegel was not content with the mechanistic worldview and did not find it to be an exhaustive approach to science (Kreines, 2004).

More specifically, we see in $§ 195$ of the Science that Hegel thought that the "objectivity" offered by modern natural science was a subjective illusion; only by (dis)placing the subject in an external and thus detached position to the object could the "objective" dogma posited by, e.g., Newton and Galileo be reached. The object would thus be seen from an

\footnotetext{
2 See e.g. Förster and Melamed (2012).

3 Mechanicism is still widely practiced today (Mammen, 2017).
} 
outside perspective and, according to Hegel, depend even more strongly on the subject and its abstract intuition. Although this displacement was not intentionally a part of the mechanicist program (but rather, as Hegel saw, a historical contingency), it was a logical consequence of applying mechanic axioms in science (Hegel, 1999, HW 4, B VI, p. 205-207). Hegel thus seized the opportunity to rearrange this logic in order to save scientific thought from the static and unreflected mechanicism that had been inherited from his predecessors (an especially present subject in his famous Preface in the Phenomenology [Hegel, 2005, 3-54]). In order to better understand this rearrangement of the ruling scientific logic, let us take a closer look at the axioms propagated by mechanicism and criticized by Hegel.

\section{Mechanicism's Five Assertions}

Galileo launched mechanicism with the dogma that "science moves forward by inferring from the most complicated observations towards the most simple symbolizations" (Galilei, 1967, p. 29). Furthermore, Descartes sedimented mechanicism with his philosophical doctrine that science could never investigate mental phenomena, making the power of blind machinery the only valid causality in science. Scientific study was thus limited to physically extended entities (Koch, 1999, p. 112) and effective and material causality (in Aristotelian lingo-see below) became the only legitimate notions through which one could explain properties, relations and phenomena.

Mechanicism can be summarized in five assertions (Beiser, 2005, p. 61-76; Kim, 2011, p. 306-9):

(1) The most basic element of the material world is physical extension; (2) thus, the primary function of matter must be to quiescently fill up empty space, and hence matter must be static and display inertia; (3) that which is effective between spatial delimited material can only be so by external effects ${ }^{4}$; (4) matter consists of (internally) indivisible atoms, and in between these atoms is only empty space (atomism) which legitimizes material causation (explanations referring to essential properties of substances); and (5) if three and four are put together, the most relevant sort of causality is a causality based on the axiom of local-realism, i.e., effective causality.

Point five further implicates that explaining a given phenomenon is only achievable by referencing to other and immediately prior events, and how these have influenced the phenomenon (which has also become known as Humean causality, and is tied to the empiricist philosophy of science).

The iron-framework of mechanicism became rusty already with the emergence of chemistry and biology. When analysing molecular and organismic systems, it is

\footnotetext{
4 It is this assertion which justifies classifying Newton's theory of universal gravitation as part of a mechanicist theory, even though this theory is not formulated in terms of contact forces. Newtonian gravitation is a mathematical description of force over distance, the impact of gravitational force diminishes as a function of distance (the square of the radius). As such, Newtonian gravity in principle requires action at a distance, and Newton himself had no issue with an interpretation assuming that gravitation was imposed on the universe by God (Gordon, 2011, p. 44). The point being that whether it be via a deity or by mathematics, the action is effectuated externally relative to the entities of the system. On a side note can be mentioned that Einstein's theory of special relativity makes do without gravitation. It was not until Einstein's theory of general relativity that gravity was explicated in such a way as to rule out action at a distance: Here, gravity is described as waves propagating at the speed of light as a result from mass-energy impacting space-time itself.
} 
necessary to operate with a spate of negatively determined causalities (e.g., forces of attraction, phase-transitions, gene-transmission). Such causes are incompatible with a conceptual system that only allows effective causality, the extension of matter, and inertia.

As a procedure of immunization, mechanicist programs propounded various rescuehypotheses. Many of these hypotheses centred around preformation, in an attempt to reduce the significance of so called morphogenetic dynamics (Koutroufinis, 2014), the reasoning being that if the entity is pre-formed, only external effects are needed to activate morphogenesis and its development, and mechanicism would thus be saved (Gleick, 2011, p. 113).

Being devoted to natural philosophy in a time of scientific unrest and upheaval, Hegel was breaking with the mechanistic preformation theory and its inability to provide explanatory power to the question of how being and becoming traverse. Hegel thus put forth his developmental logic, which was supposed to let the scientific disciplines analyse from wholes to parts instead of from parts to wholes (Hegel, 1999, HW 4, B III, p. 50-52).

\section{The Developmental Logic of Dialectics}

With the new program of natural philosophy, scientists were once again allowed to speak of remote effects, purposiveness, development, and systemic entities (Johnston, 2014, p. 33-40).

The program of natural philosophy thus developed as an antithesis to mechanicism with regard to the question of matter: Matter is not explainable as a barren inertia, but only as a powerful organization that is realized in motion (Horn, 1997; Schelling, 1985). The German natural philosophers had different perspectives on which logical considerations were best suited to describe motion (see, e.g., Valsiner, 2012, p. 79-109, and Johnston, 2008). Here, however, we are only concerned with Hegel's answer, and his answer is easiest to understand by understanding Immanuel Kant's (1724-1804) concept of natural teleology (Naturzweck) first.

In §64-65 of Kant's (2008) work Critique of Judgment he defines two principles that the analysis of development in living beings must take into account:

First of all, one must emphasize and appreciate the whole rather than the parts. Furthermore, the parts must "be combined into a whole by being reciprocally the cause and effect of their form." (Kant, 2008, p. 373). Thus, Kant does not only speak of irreducibility here. With his "whole preceding its parts" axiom he is making a stronger claim, a claim about the logical dynamics of a meaningful coherence or structure. In §76-78 Kant specifies that from this mereological perspective, a mechanism is implied where the function of the parts is determined by the continued preservation of the whole, thus creating an inner teleology. Ultimately, Kant does not believe these axioms offer any explanatory power, since he is of the opinion that the action of investigating (e.g., observing a system) in itself blocks the road for any epistemic observations to be made. Thus, the fact that supervenient dynamics can emerge from partial elements indicate some sort of telos-driven mechanism totalizing the system into a structural whole, which, for Kant, ultimately is nothing but an intuitive perspective vitally invoked when investigating organisms: a sort of rationalistic vitalism (Normandin \& Wolfe, 2013). 
Hegel, on the other hand, was convinced of the truth of this axiom, and throughout his Encyclopaedia (1999, HW, B. IV), he claims that Kant's axioms are epistemically valid (i.e., produce knowledge).

More specifically, Hegel states that, when speaking of the human subject, not only does materiality take shape but so does history (Koselleck, 2018, p. 34-40).

The human existence erects and develops through historical formations (Gadamer, 2004, p. 324) and thus the participating activity is itself the precondition of observation and not-as Kant claimed-its obstacle (Hegel, 1999, HW 4, B II, p. 31-49). ${ }^{5}$ Thus, with Hegel we see both an inner (organismic) and a historical (amongst the environs embedding the organism) teleology. Hegel not only progresses philosophy of science in overcoming Kant, he also identifies the logic of dialectics as the methodology for future thought, namely, the aspiration to analyse and synthesize theoretical elements to their consequent ends, not letting any formal principle dictate where thought must stop (Gadamer, 2004, p. 333; Huggler \& Huggler, 2002).

For Hegel, this methodology is not just the result of overcoming formalism as an ideo-historical obstacle, it is also the result of overcoming the idea that our subjective and experiential being can return to a more primordial (i.e., pre-conceptual) condition of consciousness.

Hegel termed this condition Das Bekannte (see, e.g., §15-16 of the Phenomenology), poorly translated as the "familiar" in the English translations (e.g., A.V. Miller's 1977 translation). Formalism thus appeared as a contingent antithesis to Das Bekannte, and Hegel saw it as his task to stipulate what was to substitute formalism (and thus replace Das Bekannte, the ideo-historical precursor necessarily contained in, though not reducible to, formalism).

\section{From Mechanicism to Dialectics}

The Danish researcher and psychologist Niels Engelsted has underlined many times the importance of shifting from a mechanical to a dialectical logic in research that involves the human sphere. In his latest book Catching up with Aristotle (2017, p. 42), he gives the example of an unmarried man who marries, and then after a while divorces his wife. Interpreted with classical logic, the man (A) is thus unmarried $\rightarrow$ married (no longer A) $\rightarrow$ unmarried (back to A). Hence, there is no historicity involved within classical logic; however, if this same example is perceived with the dialectical logic, the man (A) is unmarried $\rightarrow$ married (not-A) $\rightarrow$ divorced (not-not-A). Introducing historicity to the property thus means that not-A is not linearly referable to A (although it preserves properties from A) and that not-not-A is not-not linearly referable to not-A (although it preserves properties from not-A); in effect, there is a qualitative (not just quantitative) difference between being divorced (not-not-A) and being unmarried. Now, the man is suddenly not just unmarried but also divorced.

The status of the man is negated once (not-A) when he is married, and negated once more (double negation) when he is divorced (not-not-A). Thus, the dialectical logic includes historicity by logically emphasizing a productivity arising from the investigation

\footnotetext{
5 All references to Hegel's work besides the Phenomenology is from the Darmstadt six book collected works (Hauptwerke). References are structured as book number in the collection, book number in the original format of Hegel, and page identifications.
} 
of the entity in light of its properties (the status of the entity changes along with the states of its properties). Although this point could seem trivial in such a simplistic example, it is not: Within classical logic, philosophers and scientists have historically operated with positive determinations of properties, ascribing a subject its predicate, i.e., $A$ is $X$, whereby $\mathrm{X}$ is positively determined by $\mathrm{A}$ or a property belonging to A, e.g., the circle is round. Thus, since the renaissance scientists have been occupied with the question What is $X$ ? in trying to determine $X$ positively (Valsiner, 2000). To determine $X$ positively thus means to determine the nature of $X$ 's properties-properties that are effectively viewed as unchangeable components of the entity (X) (i.e., an analytical sentence). This way of determining the properties of an entity is quite effective when one seeks to establish universal laws of nature (such as gravitational force). However, there are some serious issues related to generalizing from analytical sentences that are based on a specific aspect of a positively determined entity: a positive determination cannot contain contradictions (Engelsted, 1989, p. 24). It is not difficult for us to understand why, if we go back to our example with the circle. It simply does not make any sense for us to state that a circle is square, as we have learned that a circle in its formality (and by definition) must be $360^{\circ}$ before we can count on it. In this regard, to be able to count on it means two things: (1) that we are, literally, able to do mathematical calculations with it, since (2) we can be absolutely sure that it always has the same form $\left(360^{\circ}\right)$.

The positive and mechanistic determination is thus deterministic in the sense that it is based on linearity. Hence, determining an entity positively simply does not allow for exploring (methodologically) developmental processes embedding that entity, since these processes are not positively and linearly given. Consider the concept of a critical period, which accounts for the phenomenon that some sense- and meta-modalities (e.g., language) require a certain stimulation in certain phases of the organisms life in order to develop (Kral, 2013; Vyshedskiy et al., 2017). Such phases are temporal and contingent extensions. The scientific essence of the concept of a critical period is that it might not be realized. Thus, a sensitive phase cannot be meaningfully understood through any positive determination.

This poses a problem when dealing with dynamical phenomena that are neither linear nor devoid of contradictions, such as societal or psychic phenomena.

These phenomena cannot adequately be accounted for with concepts derived from a positive science alone. For example, experience is (1) marked by subjectivity and thus is inherently contradictory and (2) is constantly negotiated and thus always already in the making; it does not make sense to explore the contingent properties of experience with positive determinations only. In the empirical world (as opposed to the mathematical realm of idealization), the reference of experience is never at a standstill, and the content of experience is never linearly caused.

If a researcher chooses to put a dynamical phenomenon (such as experience) through a "classical-logic-methods-mill," this researcher can be held accountable for entificing, that is, turning a dynamical phenomenon into a mechanical entity by hypostatizing through properties emanating from the method and not the phenomena (e.g., use of statistical significance levels or factors to determine what is of importance in a phenomena) (Valsiner, 2000).

At best, research like this is able to somewhat describe certain aspects of the phenomenon quantitatively or illuminate something about the conceptual basis of the method. At worst this research not only describes these aspects very poorly but also describe them in such an eschewed way that the researcher ends up with un-empirical abstractions that merely produce more quantity (e.g., think of the qualitative aspects and foundational 
debates included in some of Gordon Allport's (1956) original work on personality traits as opposed to the contemporary and popular notion of "Big Five").

To remedy this problem of not being able to adequately perceive qualities (i.e., properties distinguishing an entity) in research, one must look to another type of determination, namely the negative determination of properties. ${ }^{6}$ According to the dialectical logic expanded by Hegel (1999) in his Science of logic, an entity (A) is determined not by what it $i s$, but rather by what it (actively) is not. In effect, A is allowed to be more than just itself or belonging to itself, and we can thus perceive both the physical, quantitative and compositional aspects of a given phenomenon (e.g., H2O), but also what qualitative properties it entails (e.g., that water can be both solid, liquid, and plasmic). Thus, historicity is introduced to the phenomenon under study, and this is a very important point to draw from Engelsted's (2017) example.

\section{Asymmetrical Triads}

Every derivation in the logic has specificities related to the entities being specified (Houlgate, 2005; Winfield, 2012). One can say that Hegel's procedure has structural similarities to Kant's (2015) transcendental deduction of the categories (p. 129-146). Both Hegel and Kant follow a triadic composition in making conceptual derivations: Two terms are contemplated and somehow integrated or dissolved into a third term. What is peculiar to Hegel's category theory is, however, the strategy of assuming a strict asymmetry between the two terms taken as objects of contemplation, and hence an asymmetry in the logical trajectory towards a new determination (Hegel, 1999, HW 4, B III, p. 68-94).

Take as an example the infamous contemplation of being and nothing, leading to becoming. The speculative derivation of becoming is driven by an irresolvable asymmetry between the base-terms (being and nothing) and the supra-term (becoming). The asymmetry thus arises from the following circumstance: when thinking proceeds from the baseterms towards the supra-term one gets a sublation (aufgehoben), while when thinking from the supra-term and towards the base-terms one obtains a negation (Hegel, 1999, HW 3, B I, p. 51-69; Hegel, 2005, p. 67-159).

Aspects of being and nothing are preserved in becoming, but in an altered form, while the demerger of being and nothing does not preserve the structural relations between being and nothing, but negates their common form-becoming.

This illustrates how the dialectical logic is a perpetual mode of thinking which can guide the researcher's mind towards a sensitivity to transformations in the studied object: Which categories include commonalities between aspects or qualities of a researched phenomenon, and which categories exclude such commonalities?

Is such a guidance not urgently needed in light of for example the contemporary widespread usage of the notion of a tipping point? The scientific idea behind the notion of a tipping point is that certain parameters of a given system can only exceed certain threshold values with the cost of undermining the entire system ("the straw that broke the camel's back" is an idiom which illustrates the semantics of the idea of a tipping point; weight being the parameter, and the camel being the system). However, the notion of a tipping

\footnotetext{
${ }^{6}$ This distinction between properties (positive/negative) is pedagogically introduced in Engelsteds (e.g., 1984) work, where he summarizes some of the results from a long stretched dialectical materialist tradition of tarrying with Hegel's logic.
} 
point is used to characterize systems and phenomena so diverse as the global climate, ${ }^{7}$ the spread of Facebook posts, ${ }^{8}$ the spread of the COVID pandemic, ${ }^{9}$ a local forest fire in the Amazonas, ${ }^{10}$ etc. This leaves one wondering what the qualitative similarities between the development of these different systems and phenomena are, and which differences the notion of a tipping point categorically exclude. Hegel's dialectical logic, we argue, can intervene exactly at this juncture, by offering a mode of thinking that can see through these superficial similarities and instead be useful in establishing an adequate methodology, which can operationalize complex concepts such as a "tipping point" in a scientific context.

\section{Knowledge, a Struggle Between Structure and Process}

Earlier we illustrated how Hegel teased out historical contingencies as the driving force behind intellectual development. That is, the mechanicist program underwent a thrust towards subjectivism, which was alien to the mechanicists program, but nevertheless resulted from the processual unfolding of its logic. Is such a philosophy of historical contingencies not merely relativism, akin to various extreme postmodern theories of present day?

This is not the case since the wager in Hegel's theory of knowledge is, however, that the contingencies can be known. And this is where Hegel transcends Kant. Thus, Hegel builds his system on the axiom that contradictions are productive (or, to phrase it in Kantian parlance, contradictions are elements of synthetic statements) since contradictions indicate the contingencies of consciousness coming to know itself.

In more modern language, one can say that anomalies are the most vital element in the scientific process, since these reveal the conceptual blindspots, thus pushing forward theoretical and empirical work by exploring new mechanisms and nuances characterising the phenomenon under study.

This principle of in Hegel's system can be outlined by summarizing Kant and Hegel's theory of knowledge in the following simple formulas:

- Kantian Theory of Knowledge: Structure $\rightarrow+\cdots$ Process

- Hegelian Theory of Knowledge: Process $\rightarrow$ Structure $\rightarrow$ Process...

Kant and his heirs assume that knowledge is first and foremost determined by structural limitations that can be defined once and for all, and can be discovered by pondering the question how is science possible/what are the possibility conditions of knowledge. Since the sensible world has a general structure given once and for all, every observed process points back to a structural principle. The solid arrow indicates that processes are derivable from structural principles, and the dashed arrow indicates that the unfolding of processes leads the mind back to the structural principles.

\footnotetext{
7 https://www.nature.com/articles/d41586-019-03595-0

8 https://scs.georgetown.edu/news-and-events/article/7550/why-influencers-cant-achieve-tipping-point? fbclid=IwAR2pe3qshSMPbaLpNRVM1lHA1Hno_TFa0xTRoBzZQUUfv4ecIDvW1t1qRfo

9 https://www.theguardian.com/world/2020/feb/14/coronavirus-false-rumours-cost-lives-researchers

$10 \mathrm{https} / /$ www.theguardian.com/environment/2020/oct/05/amazon-near-tipping-point-of-switching-fromrainforest-to-savannah-study
} 
The Hegelian theory of knowledge views the production of knowledge as first and foremost a process, secondly giving rise to conceptual systems (from specific theories to worldviews). As such, the world is not given once and for all, every historical phase is only in partial possession of truths, and hence, knowledge is radically contingent (cf. Hegel, 1999, HW 4, B V, p. 22-30).

Hegel's system thus claims that knowledge is accumulated by irreversible transitions between worldly processes and the abstract structuration of these processes, and hence, the different world views that descent from a developing science is not derived from mechanical fixation. ${ }^{11}$

Since Hegel and Kant is in agreement about the synthesis of rationalism and empiricism, and thus agrees that the sensible world is always experienced as a juxtaposition of sensation and conceptualization, the important difference is that Hegel views structure as derived from process, such that the development of knowledge is contingent all the way down, while the Kantian view-and all its modern disguises-envisions a definable structure which all processes are expressions of.

It is interesting to view the contemporary debate of the post-modern influence on the human- and social-sciences in light of the above distinction between Kant and Hegel. The post-modern or post-structural turn is often explained as a critique of so-called grandtheories (Marxism, Psychoanalysis, structuralism etc.) and the tendencies of these to generalize phenomena in accordance with their own concepts. But in spite of the explicit intentions of Foucault, ${ }^{12}$ do terms like episteme, discourse, and dispositive not exactly represent conceptual packages into which centuries of empirical matters can be ordered without any remainder? In contrast, the theories of Marx and Freud all contain immanent constraints, such that the theory limits itself/reveals its own gaps. This happens by virtue of the contingencies of the empirical matters which the theory seeks to explain. For Marx this is exemplified in his failure to situate the Chinese mode of production into the analysis of the spread of the capital, and for Freud this is exemplified in the navel of the dream, the point at which the interpretation of a dream spirals into opaqueness (Žižek, 2014, p. 116-125). Hence, one is inclined to situate classic grand theories with the Hegelian axiom of contingency (where structure is encapsulated by process) and situate post-structural analysis on par with the Kantian mode of necessity (where structure and process align themselves without any remainder).

Throughout Hegel's system, this axiom of contingency is explicated through various modalities. The dictum of consciousness being defined by self-consciousness is one of them.

\footnotetext{
${ }^{11}$ In this regard, the concept of "Aufhebung" (often translated as "sublation") is relevant to shed light on, in order to reject any claims that Hegel's theory is marked by historical determinism. Elsewhere we argue that: "the initial elements have been dissolved only to be reconfigured at a higher order of complexity: as such, the transmission presupposes the initial elements (in their analogue existence), yet this new order (the digital representation) is not reducible to them." (Ebbesen \& Olsen, 2018a, b, p. 15). Thus, interpreted like this, should anything be predetermined in Hegel's philosophy of history it is only this principle of dialectics, not the concrete manifestations of a specific order per se. For a thorough philosophical discussion of Hegel's infamous absolutism on various themes besides history (society, subjectivity and science), see e.g., Malabou (2005), Žižek (2012, 2014) or Dolar (2015).

${ }^{12}$ Foucault famously being the spokesman for working with flexible and dynamic terms, never settling for an overarching conclusion.
} 


\section{Consciousness Is Defined by Self-consciousness}

For in-itself is consciousness; but equally it is that for which an other (the in-itself) is; and it is for consciousness that the in-itself of the object, and the being of the object for an other, are on and the same; the 'I' is the content of the connection and the connecting itself.

(Hegel, 1977, p. 104).

In the above quote Hegel draws heavily on self-referential dynamics to explicate consciousness. Consciousness is relevant for philosophy of science for several reasons. Science often studies systems and entities which necessitates that aspects or properties of consciousness be taken into account. For example, the study of mental systems or entities, from aetiology to psychology, leads us to consider how knowledge, learning potential, and communicative abilities of organisms are structured and develop, and the researcher must have a keen eye towards species specificity (intraspecies and interspecies variation) and individuality (intraindividual and interindividual variations) (Wimsatt, 1980).

Another example is the study of organizations, from history to sociology, where agency and choice are important factors in determining the structural order of things (e.g., Archer, 1995).

Both fields thus require aspects of consciousness to be included into the axiomatic base of the research project.

At the heart of all scientific disciplines thus lie a dynamical relationship between the researcher's intellect and her sense-modalities, and it is crucial to contemplate this relationship as a necessary starting point before any empirical investigation can begin: A coherent philosophy of science must be able to account for such metaphysical dynamics-from quantum physics to theology (Wimsatt, 2007, p. 47).

It is in this regard that Hegel's philosophy of consciousness is relevant for philosophy of science. Hegel envisions consciousness as driven by self-referential dynamics, leading to an epistemic connection of subject and object conceptualized as reflexion (Hegel, 1999, HW 4, B III, p. 249-255).

\section{Towards a Nuanced View of the Epistemic Access of Thought}

In Danish, reflexion is translatable as genspejling which is different from mere mirroring which is the ideas suggested by the English word reflect. The Slovenian philosopher SlavojŽižek(1949-)has proposed the term parallax (Žižek, 2006)as anenglish characterization of Hegel's concept of Reflexion.

A parallax is a term adopted from astronomy. It denotes the angular displacement of a line of sight that happens towards an object when the observer changes position. Hence, the concept of parallax has a semantics which includes the simultaneous displacement and entanglement of the observer and the observed, and the term thus captures the contingent dynamics of subject and object, which is a key part of Hegel's dialectics. Furthermore, as we will argue shortly, the parallax concept also helps differentiate reflexion from the phenomenology of self-reflection, as it is developed through Hegel's phenomenology (Hegel, 2005, p. 92-119).

If Kant crossed the border from dogmatism to critical enlightenment by posing the condition of possibility question, how is my knowing possible, Hegel crossed the border by 
posing the question how can appearances be simultaneously deceiving and truth carrying vehicles (our interpretation of Huggler and Huggler (2002) walkthrough of Hegel's programmatic youth writings).

Hence, when Hegel describes the I as being both a relation and the content of a relation at the same time, he is straining thought to conceive of structure and process, permanence and change, in a way that does not one-sidedly settle for essence or appearance, abstraction or concretion. ${ }^{13}$ Hegel thus constructs an alternative characterization of the knowledge obtaining mind, than the epiphenomenal one inherent to mechanicism, and he thereby stipulates a new metaphysical distinction of consciousness necessary for a determination of the modern subject (Hegel, 2005). That distinction is the distinction between observation and experience.

\section{Observation and Experience}

The distinction between observation and experience signifies two modalities of reflective thought: To reflect upon oneself-self-reflection-is a defining characteristic of consciousness, and thus, experience is in principle inseparable from self-reflection; they are two moments of the same form of consciousness. Observation-in contrast-requires that the subject reflects upon the content of its perception; they are two forms of consciousness united as one moment. Hence, experience and self-reflection are intertwined in this phase oscillatory dynamic, and observation and reflection are intertwined in the dynamics of the parallax.

With the distinction between experience and observation, Hegel explicates a philosophy with crucial constraints of the philosophical process. The researcher cannot both experience and reflect upon the experience at the same time. Self-reflection and experience change priority in a discrete manner. Experience does involve all available sensemodalities. However, when it comes to research, it is merely a matter of which modalities are prioritized. In scientific research, this is a prioritization performed in the direction from reflection towards the senses, whereas in the explorations of sense-specified artforms (e.g., music and painting), the modality runs from the sensuous realm towards reflection. If you study dance by dancing, you prioritize tactile and kinesthetic data; if you study dance by filming it, you prioritize visual data; if you study dance by interviewing dancers, you get specific auditive and generally lingual data: One sense-modality can only be prioritized if another are down-regulated.

In contrast, yet complementary to the theorem of experience, observation and reflection changes priority in an analogue way. Any observation requires reflective preparation, which is not simply a restatement of the cliché of observations being theory-laden. The idea of theory-ladenness masks a latent empiricism, insinuating that there is a realm of pure observations behind our theories.

Through a Hegelian perspective on the relation between observation and experience one is able to see that the theory-ladenness of observation goes all the way down. When we speak of scientific findings and scientific investigations in everyday debates, we would do very well to remember that no amount of data can make a statement scientific. A statement

\footnotetext{
13 This is most radically expressed in the introduction to the Phenomenology of Spirit where Hegel conceptualizes the "Absolute, not only as Substance, but also Subject" (Hegel, 2005, p. 59).
} 
only obtains its status as scientific by its placement in a theory which logically connects various findings. Hence, the scientific observation is constituted by a theoretical leakage onto our perceptual apparatuses (Gregersen \& Køppe, 1985).

What is taken into account during an observation is delimited by the reflecting subject (which was exactly what Hegel criticised the mechanicists for neglecting, as we saw earlier) even though it is the content of the observation which is supposed to inform the reflection.

Hence the parallax, the fundamentality of displacement in the epistemic process.

\section{The Scientific Subject: In Between experience and Observation}

We can now deepen our understanding of the Hegelian sentence that consciousness is self-consciousness, since we can now meaningfully state that the poles of experience and observation are equally defining of the subject.

As Hegel puts it in the second book of the logic (book of essence): "Quality, through its relation, passes over into other; in its relation its alteration begins. The determination of reflection, on the other hand, has taken its otherness back into itself" (Hegel, HW 3, B II, p. 408). We understand this in continuation of the phenomenological distinction between observation and experience; thus, the determination of qualities (modelling empirical matters) are contingent upon the material constraints of experience (the irreversibility of measurements, the historical heritage of concepts and perspectives, the conditions of education, etc.), and it is this very limitation, which the scientific project has incarnated into human existence via the craft of observation and archivation (the circular preparation of what parameters to observe and which modalities to focus through).

\section{Concluding Remarks: Dialectics as the Metaphysical Route to Science}

Hegel has offered us a way to think about history, logic and the formation of knowledge, which seems utterly heretic to the modus of present day academia.

When philosophy of science is taught as a choice between cognitivism and cultural studies, then fundamental questions are evaded (e.g., the relation between meta-theory and theory) and scientific progress is stalled; it makes it seem as if the parts and wholes, structures and processes, and historicity and objectivity of a research area are simply opposed. The fruits of the dialectical tree of knowledge are left to rot. Contemporary deadlocks in philosophy of science (relativism/realism, disavowals of causality, methodic dogmatism, etc.) are all partially based upon a reluctance to recognize and delve deeper into a series of necessary and complex metaphysical crossroads.

Eventually, history forces all researchers interested in development to face these crossroads.

By setting into motion subject and object, contingency and necessity via the dialectical treatment of logic and history, Hegel has offered us a qualitatively new way of thinking about these deadlocks, a way of thinking which can lead to a stronger developmental science by explicating the relation between the empirical matter at hand and the abstract representation of it. 


\section{References}

Allport, G. (1956). Becoming. Nyt Nordisk Forlag.

Archer, M. (1995). Realist social theory: The morphogenetic approach. Cambridge University Press.

Beiser, F. C. (2005). Hegel. Routledge.

Brandom, R. B. (2019). Hegel and analytic philosophy. Analysis, Madrid, 23(2), 1-20.

Bunge, M. (2012). Evaluating philosophies. Springer.

Burke, P. (2015). What is the history of knowledge. Polity Press.

Copilas, E. (2019). Coping with the unconscious. (p. 23). Hermeneia.

Dolar, M. (2015). The Owl of Minerva from dusk till dawn, or, two shades of gray. Filozofija $i$ društvo, 26(4), 875-890.

Ebbesen, D., \& Olsen, J. (2018a). Motor intention/intentionality and associationism. A conceptual review. Integrative Psychological and Behavioral Science, 52(4), 565-594.

Ebbesen, D., \& Olsen, J. (2018b). Ontogenetic development of symbolicity. Human Arenas, 2, 99-128.

Engelsted, N. (1989). Personlighedens almene grundlag. Århus Universitetsforlag.

Engelsted, N. (2017). Catching up with Aristotle. SpringerBriefs.

Förster, M., \& Melamed, Y. (2012). Spinoza and German Idealism. Cambridge University Press.

Gadamer, H. G. (2004). Sandhed og metode. Grundtrak af en filosofisk hermeneutik. Systime.

Galilei, G. (1967). Dialogue concerning the two chief world systems-Ptolemaic and Copernican. UCLA Press.

Gleick, J. (2011). Chaos. Making a new science. Open Road Media.

Gordon, B. (2011). The rise of naturalism and its problematic role in science and culture. In: Examining the role of naturalism in science. Delaware: Intercollegiate Studies Institute.

Gregersen, F., \& Køppe, S. (1985). Videnskab og lidenskab: Om humanioras videnskabsteori, videnskabssociologi, videnskabshistorie og samfundsmassighed. Tiderne Skifter.

Hegel, G. W. F. (1999). Hauptwerke in sechs Bänden. Felix Meiner Verlag.

Hegel, G. W. F. (1977). Phenomenology of spirit. English translation by A.V. Miller. Oxford University Press.

Hegel, G. W. F. (2005). Åndens Fanomenologi. Gyldendal.

Hegel, G. W. F. (1801/2002). Differensen mellem det Fictheske og det Schellingske filosofiske system $i$ forbindelse med Reinhold's "Bidrag til lettere oversigt over filosofiens tilstand i begyndelsen af det nittende århundrede, forste hafte". Udgivet i Slagmark nr. 36. s. 13-40.

Horn, F. (1997). Schelling and Swedenborg: Mysticism and German idealism. Swedenborg Foundation.

Houlgate, S. (2005). The Opening of Hegel's logic: From being to infinity. Purdue University Press.

Huggler, J., \& Huggler, L. (2002). Substansen er subjekt. Slagmark - Tidsskrift for idéhistorie, 36, 91-126.

Hviid, P., \& Villadsen, J. (2014). Cultural identities and their relevance to school practice. Culture and Psychology, 20(1).

Johnston, A. (2008). Zizek's ontology. Northwestern University Press.

Johnston, A. (2014). Adventures in transcendental materialism: Dialogues with contemporary thinkers. Edinburgh University Press.

Kant, I. (2008). The critique of judgement. [Reprint.]. Trans. James Creed Meredith. Clarendon Press.

Kant, I. (2015). Critique of pure reason. Philosophical Library/Open Road.

Kim, J. (2011). Philosophy of mind. Westview Press.

Keenan, D. (2004). Hegel and contemporary continental philosophy. State University of NY Press.

Koch, C. H. (1999). Descartes. Centrum.

Koselleck, R. (2018). Sediments of time: On possible histories. Stanford University Press.

Koutroufinis, S. (2014). Life and process: Towards a new biophilosophy. Walter de Gruyter.

Kral, A. (2013). Auditory critical periods: a review from system's perspective. Neuroscience, 247.

Kreines, J. (2004). Hegel's Critique of pure mechanism and the philosophical appeal of the Logic project. European Journal of Philosophy, 12(1), 38-74.

Malabou, C. (2005). The future of Hegel: Plasticity, temporality and dialectic. Routledge.

Mammen, J. (2017). A new logical foundation for psychology. SpringerBriefs.

Mammen, J., \& Mironenko, I. (2015). Activity theories and the ontology of psychology. Integrative Psychological and Behavioral Science, 49(4).

Normandin, S., \& Wolfe, C. T. (2013). Vitalism and the scientific image in post-enlightenment life science, 1800-2010. Springer, Netherlands.

Pedersen, D., Stjernfelt, F., \& Køppe, S. (2015). Kampen om disciplinerne. Viden og videnskabelighed $i$ humanistisk forskning. Hans Reitzel.

Pedersen, S., \& Bang, J. (2016). Youth development as subjectified subjectivity-a dialectical-ecological model of analysis. Integrative Psychological and Behavioral Science, 50(3). 
Pfeifer, G. (2012). The new materialism: Althusser, Badiou and Zizek. Scholar Commons.

Popper, K. (2012). The open society and its enemies. Taylor and Francis.

Redding, P. (2020/1997). Georg Wilhelm Friedrich Hegel. The Stanford Encyclopedia of Philosophy. Stanford University: Metaphysics Research Lab.

Sartre, J. (1978). Critique of dialectical reason. Theory of Practical Ensembles. NLB.

Schelling, F. W. J. (1985). On the relationship of the philosophy of nature to philosophy in general. In: Between Kant and Hegel. Albany Press.

Valsiner, J. (2000). Culture and human development. Sage Publications.

Valsiner, J. (2012). A guided science: History of psychology in the mirror of its making. Transaction Publishers.

Vyshedskiy, A., Mahapatra, S., \& Dunn, R. (2017). Linguistically deprived children: Meta-analysis of published research underlines the importance of early syntactic language use for normal brain development. Research Ideas and Outcomes, 3.

Wimsatt, W. C. (1980). The units of selection and the structure of the multi-level genome. PSA: Proceedings of the Biennial Meeting of the Philosophy of Science Association, 2.

Wimsatt, W. C. (2007). Re-engineering philosophy for limited beings: Piecewise approximations to reality. Harvard University Press.

Winfield, R. D. (2012). Hegel's science of logic: A critical rethinking in thirty lectures. Rowman \& Littlefield Publishers.

Žižek, S. (2006). The parallax view. MIT Press.

Žižek, S. (2012). Less than nothing. Hegel and the shadow of dialectical materialism. Verso Books.

Žižek, S. (2014). Absolute recoil: Towards a new foundation of dialectical materialism. Verso.

Publisher's Note Springer Nature remains neutral with regard to jurisdictional claims in published maps and institutional affiliations. 